\title{
A LITERATURE REVIEW OF HIGHER EDUCATION REFORM AND LIFELONG LEARNING IN A DIGITAL ERA
}

\author{
Marcia Håkansson Lindqvist, Peter Mozelius, Jimmy Jaldemark, Mid Sweden University,
} Sweden, Martha Cleveland-Innes, Athabasca University, Canada

\begin{abstract}
Policy documents have long emphasized lifelong learning, social development, global competition and employability. At the same time, how higher education needs to be transformed to meet this demand for creating opportunities for lifelong learning is an important issue. This study seeks to take on the literature through the exploration of two main constructs: lifelong learning and higher education reform, answering the question of which key themes of lifelong learning, if any, are emerging in higher education reforms. Using a systematic review of relevant, foundational, and current published literature on lifelong learning and higher education reform, the twostep selection of the publications is presented. Key themes are discussed as well as next steps in the continued study with the systematic literature review in which selected articles will be read by and expert panel. How lifelong learning and higher education reform can create a diverse higher education system which will address diverse students and required competencies in diverse, dynamic societies will be of importance for future study.
\end{abstract}

Keywords: Higher education reform, Lifelong learning, Systematic literature review

\section{Introduction}

Lifelong learning is an issue that has been under debate for many years. Among other things, its place in the educational system has been discussed. In the past, many reforms have been introduced to enable opportunities for lifelong learning. These reforms have discussed the different shape it takes, such as issues relating to formal, non-formal and informal aspects of learning from a lifelong and life wide perspective. Moreover, these reforms have linked lifelong learning to the development of the society. Therefore, transnational organisations and countries all over the world have included the concept of lifelong learning in their policy documents. These policy documents have various motives for emphasising lifelong learning; social development, global competition, employability, 
and so on (Jaldemark, 2020). What they have in common is the aim to transform the educational system to enable the creation of opportunities for lifelong learning.

This transformation and policy development also link to the emerging digitalization, another global societal trend that intersects with the rising emphasis on lifelong learning. From an educational perspective, the emerging digitalization is a process that changes the conditions for learning and communication between humans by enabling multiple and innovative ways of combining places, time-zones, and digital technologies and resources. This trend impacts educational systems in general and higher education in particular by including innovative and transformative opportunities for learning that enable asynchronous and synchronous participation in formal, informal, and non-formal educational settings.

Policies that discuss the transformation of higher education to include digitalization and lifelong learning is common. These policies emphasize the need to be up-to-date with the impact the emerging digitalisation has on working life and the role of higher education in changing the society. This leads to ideas of transforming the role higher education have in national educational systems as well on a global scale. Therefore, both the rising emphasis on policies that enable development of opportunities for lifelong learning and the emerging digitalization creates new conditions for being a citizen. Therefore, this paper aims at discussing reformation of higher education in the light of the rising emphasis on lifelong learning and the emerging digitalization. The development discussed above sums up in the following research questions:

- How does lifelong learning fit into the current digital trends of higher education reforms?

- Which key themes of lifelong learning are emerging in higher education reforms?

\section{Background}

We draw from a historical and growing literature to explicate the two main constructs in this study: lifelong learning and higher education reform. Below we identify seminal thinking about these two interrelated phenomena and a rationale for studying them together. Although this scholarly work commenced prior to the 2020 Covid-19 global pandemic, the needed response to such an event only highlights the need for agile, competent lifelong learning. Everyone had much to learn in short periods of time from many information sources with varying levels of accuracy. The adjustments to higher education structures during the pandemic adds evidence to our argument as learning design and delivery changed in the name of needed flexibility and multi-modal learning. Required changes in higher education, combined with the need for lifelong learning that is well-planned and implemented, can have wide reaching and valuable outcomes. In this 
phase of our study, we seek to systematically identify and review literature that addresses the following question: Which key themes of lifelong learning, if any, are emerging in higher education reforms?

\section{Evidence of a need for lifelong learning}

Given that societies are increasingly dynamic, globally connected, and socio-economically complex, there is a need to foster technology-enabled digital lifelong learning capabilities among societal members. This is one of many reform requests laid at the academic doors of higher education institutions. Learning across one's lifetime is captured in the phrase lifelong learning and is defined by Jarvis (2014) as a process where individuals of any age and with broad interests acquire knowledge and skills. Established teaching institutions is one way of delivery, but not the only one (p.53). Higher education institutions can play two roles in the lifelong learning space. They can ensure that graduates of formal, credit, and accredited programs are empowered with skills required to be a lifelong learner. Those same institutions can also offer continuing and extension education courses and programs designed for the needs of prospective and current lifelong learners. The delocalization of education programs through the affordances of digital resources and technology-enabled learning applies when designing for lifelong learning as well as traditional programs. This fact alone positions higher education institutions to be central, if not the only, purveyors of lifelong learning.

Seminal thinking is found in Delor's et al. (1996) four pillars of learning as fundamental principles for embracing lifelong learning. This work applies in both the roles of higher education can play for lifelong learning identified above. Learning to know means that education should provide the cognitive tools required for an individual to better comprehend the world and its complexities, and to have an appropriate and adequate foundation for future learning. Learning to know can be understood as a synonym of learning to learn in order to benefit from the opportunities offered by lifelong learning. Learning to do focuses on acquiring professional qualifications and soft skills such as the ability to cope with diverse situations and to work in a team. Education should provide the skills to help enable individuals to effectively participate in the global economy and society. Learning to live together focuses on developing an understanding of others and the reality of interdependence relating to human rights, democratic principles, intercultural understanding, and peace and harmony at all levels of society. Learning to be requires that education provide self-analytical and social skills to enable individuals to develop to their fullest potential as a whole person: psycho-socially, affectively, and physically. 


\section{Current trajectories of higher education reform}

For Broucker, de Wit, and Leisyte (2016), higher education reform will include a restructured public sector. By contrast, Williams (2016) identifies a need for a more socially appropriate response from education; education not just for maintaining the status-quo or in support of the elite, but instead toward the greater good. From either view, here are opportunities for education to better align to the needs of students and society. Multiple societal transformations, acting as a catalyst for higher education reform, are identified in published literature (Bryce, Iglesias, Pullman, \& Rogova, 2016; Duderstat, 2009; Keeling \& Hersh, 2011). These transformations include:

- information access and quality;

- cost-containment and affordability;

- globalization of human activities;

- employment sector transformation;

- $21^{\text {st }}$ century core capabilities,

- continuous technology expansion and integration;

- changing student demand, demographics, and resulting needs.

The need to reform higher education in line with societal changes is well articulated in government documents and academic literature (Jones, 2013). A systematic approach to turn such demands into reforms, with an evidence-base to guide such action, underpins this study.

We note the previous work of Slowey and Schuetz (2002) who identified a new way of seeing higher education in reference to society. For Slowey and Schuetz, traditional forms of delivery are often missing attention to the needs of more diverse learners. They suggest this attention to diverse needs will embrace the needs of lifelong learners, putting the campus into what can be called "lifelong learning mode" (Schuetze \& Slowey, 2002; p.324). A move toward a lifelong learning mode of delivery can address the broader demands for change in higher education coming from government agencies and the students themselves. A diverse higher education system will address needs of diverse students and the required competencies in diverse, dynamic societies. (Cleveland-Innes, 2020).

\section{Method}

This study begins with a systematic review of relevant, foundational, and current published literature on lifelong learning and higher education reform. Proposing any new conceptual relationships without thorough reference to existing empirical and theoretical evidence creates poorly constructed tests of new relationships. This is particularly erroneous in the practice-oriented, social science field of education; garbage in, garbage out and ineffective educational practices are the result. According to Auger (2009), "social scientists face the 
problem of information overload. Indeed, the provision of scientific information largely exceeds the human capability of absorbing it all" (p.1032). Common reviews of the literature, while helpful, are often "inconsistent, non-critical and unsystematic reviews" (ibid; p.1032).

This systematic review of identified literature addresses our central question about the relationship between lifelong learning and higher education reform. In doing so, we "adhere closely to a set of scientific methods that explicitly aim to limit systematic error ... in order to answer a particular question" (Petticrew \& Roberts, 2006; p.9) or questions. Petticrew and Roberts offer a well-used seven-step approach to systematic reviews of the literature in the social sciences that goes well beyond the usual mathematical models of meta-analyses in order to answer questions about human experiences (Suri \& Clarke, 2009). We seek conceptual definitions, common practices, measurement options, and possible conceptual overlaps, if any, between higher education reform and lifelong learning. The following information outlines the selection process for, and the listing of, published resources used in the study.

After discussions and an agreement on a focus on technology enhanced or technology enabled lifelong learning and workplace learning in higher education, the first search string was composed as: ("Lifelong learning" OR "Workplace learning”) AND "Higher education (change OR reform OR policy)" AND ("technology enabled" OR "technology enhanced" OR "blended learning” OR "informal learning" OR "non-formal learning”). A search string with an ending that should not only find studies on formal learning, but also on non-formal and informal learning resulted in approximately 3,500 hits in Google scholar. This was too high a percentage of white papers, position papers and conference articles with weak methodology. Furthermore, the high percentage of articles on the more technical aspects of technology enabled or technology enhanced learning also seemed too high.

The next step to fine-tune the search was to set some inclusion/exclusion criteria and to modify the search string. Like most other research fields this is an evolving one, and the first criterion was set to only include articles and book chapters published in 2016 or later. The other criteria were to exclude white papers, low quality position papers, studies with poor research methods, and articles that did not relate to the aim of this study. To retrieve fewer technical studies and to get a better focus on change, reform and policy in higher education the search string was modified to: "Lifelong learning" OR "Workplace learning") AND "Higher education (change OR reform OR policy)" AND ("blended learning” OR “informal learning” OR "non formal learning”). After a quality assessment according to the inclusion/exclusion criteria, 26 articles were selected for further close reading. 


\section{Findings}

As noted above, after a quality assessment according to the inclusion/exclusion criteria, we selected 26 articles for further close reading. The selected publications with selected themes can be found in Table 1 in the next section below.

Table 1: $\quad$ Set of publications and selection of themes

\begin{tabular}{|c|c|}
\hline Publication & Selection of themes \\
\hline $\begin{array}{l}\text { Asfiati, A., \& Wekke, I. S. (2019). Lecturers' participation in applying blended } \\
\text { learning in Islamic higher education in Indonesia. Universal Journal of } \\
\text { Educational Research, 7(12), 2604-2608. }\end{array}$ & $\begin{array}{l}\text { Blended learning, improved student } \\
\text { skills for lifelong learning. }\end{array}$ \\
\hline $\begin{array}{l}\text { Baptista, A. (2016). Revisiting lifelong learning in light of the Bologna process } \\
\text { and beyond. Lifelong learning: Concepts, benefits and challenges, 17-35. }\end{array}$ & Lifelong learning, Bologna process. \\
\hline $\begin{array}{l}\text { Boyadjieva, P., \& llieva-Trichkova, P. (2018). Lifelong learning as an } \\
\text { emancipation process: A capability approach. In The Palgrave international } \\
\text { handbook on adult and lifelong education and learning. (pp. 267-288). } \\
\text { London: Palgrave Macmillan. }\end{array}$ & $\begin{array}{l}\text { Lifelong learning, social and } \\
\text { institutional contexts, values. }\end{array}$ \\
\hline $\begin{array}{l}\text { Bohlinger et al (2016). Validation of non-formal and informal learning in } \\
\text { Europe: Research, policies, legitimacy and survival. In Souto-Otero, M. } \\
\text { Education policy. Frankfurt/Main: Peter Lang. }\end{array}$ & $\begin{array}{l}\text { Policy-making in validation of } \\
\text { nonformal and informal learning, } \\
\text { exclusion and inclusion. }\end{array}$ \\
\hline $\begin{array}{l}\text { Bridgstock, R. (2017). The university and the knowledge network: A new } \\
\text { educational model for twenty-first century learning and employability. In } \\
\text { Graduate employability in context (pp. 339-358). London: Palgrave } \\
\text { Macmillan. }\end{array}$ & $\begin{array}{l}\text { Employability, new university model } \\
\text { as experiential, social and networked. }\end{array}$ \\
\hline $\begin{array}{l}\text { Cleveland-Innes, M. (2020). Student Demographic Change and Pedagogical } \\
\text { Issues in Higher Education. In Inequality, Innovation and Reform in Higher } \\
\text { Education (pp. 159-173). Springer:Cham. }\end{array}$ & $\begin{array}{l}\text { Needed shift in } \mathrm{HE} \text {, student } \\
\text { characteristics and needs, levitating } \\
\text { pressure on faculty. }\end{array}$ \\
\hline $\begin{array}{l}\text { Gaebel, M., Zhang, T., Bunescu, L., \& Stoeber, H. (2018). Learning and } \\
\text { teaching in the European Higher Education Area. European University } \\
\text { Association asbl. }\end{array}$ & $\begin{array}{l}\text { Collaboration across universities, } \\
\text { inclusion of other stakeholders. }\end{array}$ \\
\hline $\begin{array}{l}\text { Ishak, M. M., Ali, H., Rahim, F. A., Bakar, M. S. A., Ariffin, T. F. T., \& Malaysia, S. K. } \\
\text { (2018). Managing Learning and Teaching Orientation of Online Centered } \\
\text { Approaches in Higher Learning: “MOOC" and Beyond. In Educational Access } \\
\text { and Excellence, 1, } 119 .\end{array}$ & $\begin{array}{l}\text { Collaborative management approach, } \\
\text { globalised online learning, learning } \\
\text { and teaching. }\end{array}$ \\
\hline $\begin{array}{l}\text { Jacobs, A. H. M. (2018). Values, institutional culture and recognition of prior } \\
\text { learning. South African Journal of Higher Education, 32(4), 96-106. }\end{array}$ & $\begin{array}{l}\text { Critical hermeneutics, } \mathrm{HE} \text {, policy, } \\
\text { culture, values. }\end{array}$ \\
\hline $\begin{array}{l}\text { Jamaludin, R., McKay, E., \& Ledger, S. (2020). Are we ready for Education } 4.0 \\
\text { within ASEAN higher education institutions? Thriving for knowledge, } \\
\text { industry and humanity in a dynamic higher education ecosystem. Journal of } \\
\text { Applied Research in Higher Education. }\end{array}$ & $\begin{array}{l}\text { Educational ecosystems in } \mathrm{HE} \text {, seeking } \\
\text { Education 4.0. }\end{array}$ \\
\hline Kagan, C., \& Diamond, J. (2019). Massification of Higher Education and the & Policies and practices to embrace \\
\hline $\begin{array}{l}\text { Nature of the Student Population. In University-Community Relations in the } \\
\text { UK (pp. 51-76). Palgrave Macmillan, Cham. }\end{array}$ & $\begin{array}{l}\text { diverse populations in widening } \\
\text { participation in } \mathrm{HE} \text {. }\end{array}$ \\
\hline $\begin{array}{l}\text { Kasworm, Carol. "Adult Workers as Learners in the USA Higher Education } \\
\text { Landscape." In Inequality, Innovation and Reform in Higher Education, pp. } \\
\text { 221-235. Springer, Cham, } 2020 .\end{array}$ & $\begin{array}{l}\text { Need for HE to rethink mission, target } \\
\text { student clientel, specific focus on } \\
\text { adult Higher Education. }\end{array}$ \\
\hline $\begin{array}{l}\text { Lim, C. P., \& Wang, T. (2016). A framework and self-assessment tool for } \\
\text { building the capacity of higher education institutions for blended learning. } \\
\text { In Blended learning for quality higher education: Selected case studies on } \\
\text { implementation from Asia-Pacific, } 1-38 \text {. }\end{array}$ & $\begin{array}{l}\text { Capacity building in } \mathrm{HE} \text { and the } \\
\text { capacity of to drive, sustain and scale } \\
\text { up their blended learning practices. }\end{array}$ \\
\hline $\begin{array}{l}\text { Matheos, K., \& Cleveland-Innes, M. (2018). Blended learning: Enabling higher } \\
\text { education reform, Revista Eletrônica de Educação, 12(1), 238-244. }\end{array}$ & $\begin{array}{l}\text { The need for blended learning to } \\
\text { situate itself, timely and crucial HE } \\
\text { Reform }\end{array}$ \\
\hline $\begin{array}{l}\text { Petersone, M., Krastins, A. V., \& Ketners, K. (2016). Implementation of Lifelong } \\
\text { Learning for Improving Customs Education System in Latvia and the World. } \\
\text { International Journal of Education and Learning Systems, 1, 27-36. } \\
\text { Sá, M. J., \& Serpa, S. (2018). Transversal competences: Their importance and } \\
\text { learning processes by higher education students. Education Sciences, 8(3), }\end{array}$ & $\begin{array}{l}\text { Lifelong learning opportunities for the } \\
\text { implementation of measures to } \\
\text { improve the education system. } \\
\text { Cross-disciplinary training towards } \\
\text { continuous, lifelong learning. }\end{array}$ \\
\hline
\end{tabular}
126 


\section{A Literature Review of Higher Education Reform and Lifelong Learning in a Digital Era}

Santos, L., Bago, J., Baptista, A. V., Ambrósio, S., Fonseca, H. M., \& Quintas, H. (2016). Academic success of mature students in higher education: a Portuguese case study. European Journal for Research on the Education and Learning of Adults, 7(1), 57-73.

Sheridan, L., Gibbons, B., \& Price, O. (2019). Achieving WIL Placement and Theoretical Learning Concurrently: An Online Strategy for Higher Education Institutions. Journal of University Teaching and Learning Practice, 16(3), 8. Smith, G. A. (2019). Framing Faculty Development as Workplace Learning, Journal on Centers for Teaching and Learning, 11, 3-23.

Souto-Otero, M. (2016). Validation of non-formal and informal learning in Europe: Research, policies, legitimacy and survival. Education policy. Frankfurt/Main: Peter Lang.

Spring, K., \& Graham, C. (2017). Thematic patterns in international blended learning literature, research, practices, and terminology. Online Learning Journal, 21(4).

Tikhonova, E.N., \& Raitskaya, L. (2018). An Overview of Trends and Challenges in Higher Education on the Worldwide Research Agenda. Journal of Language and Education, 4(4 (16).

Unluhisarcikli, O. (2018). Informal workplace learning experiences of graduate student employees. Australian Journal of Adult Learning, 58(1), 66. Volungevičienè, A., Teresevičienè, M., \& Ehlers, U. D. (2020). When is open and online learning relevant for curriculum change in higher education? Digital and network society perspective. Electronic journal of e-Learning. Webb, S., Dunwoodie, K., \& Wilkinson, J. (2019). Unsettling equity frames in Australian universities to embrace people seeking asylum. International Journal of Lifelong Education, 38(1), 103-120.

Weil, M., \& Eugster, B. (2019). Thinking outside the box: De-structuring continuing and higher education. Disciplinary Struggles in Education.Table
Explores the academic success of mature students in HE.

Dynamic Systems Development. Method (DSDM) for supporting work integrated learning and internships.

Social workplace learning, for teacher development.

Importance of validation for EU-policy and the consequences related to exclusion and inclusion.

Informal workplace learning experiences of graduate students.

The transformation of $\mathrm{HE}$, student teacher relationship, social equity and access to $\mathrm{HE}$.

Conditions for workplace learning and informal learning, PhD-students. Open online learning for curriculum change in $\mathrm{HE}$ to respond to digital and network society learning needs. Explores university access for for refugees and people seeking asylum.

Comparison of $\mathrm{HE}(\mathrm{HE})$ and

Continuing. Education Training (CET) in qualifications.

\section{Discussion}

In returning to the research question, which key themes of lifelong learning, if any, are emerging in higher education reforms, the review of the 26 articles resulted in a selection of five articles. These publications can be said to represent and characterize global themes regarding challenges in creating a closer connection between lifelong learning and $\mathrm{HE}$ of interest for continued and deeper study. The first article selected was Baptista (2016), which drawing upon European policy presents LL for economic development, personal development, social inclusiveness and democratic understanding and activity in HE. Kasworm (2020) argues for a rethinking of the mission of HE with a specific focus on adult undergraduate students who more often are workers as well as students. Boyadjieva and Ilieva-Trichkova (2018) provide a theoretical outline of the heuristic potential of the capability approach in conceptualizing lifelong learning and the capacity of this approach to guide empirical studies on lifelong learning. A stronger relationship between $\mathrm{HE}$ research and CET professional activity such as more collaborative engagement between $\mathrm{HE}$ and CET is necessary to include the importance of applied, practitioner research in professional fields is explored in the fourth article by Weil and Eugster (2019). The final article, Jamaludin and Ledger (2020), presents the challenges seen in HE and the need for a new dynamic HE ecosystem and Education 4.0. Together we viewed these articles to 
encompass multiple societal reforms pushing towards reform of HE (Bryce, Iglesias, Pullman, \& Rogova, 2016; Duderstat, 2009; Keeling \& Hersh, 2011).

\section{Conclusions and next steps}

In further study, this review has provided deeper insights into the necessary changes and reform in HE to create and promote beneficial conditions for lifelong learning and higher education along with forms of higher continuing education. In the next step of the review, we will present these five articles for close reading by an expert panel in line with the Delphi method (Brady, 2015). The comments and insights of the expert panel will provide a deeper understanding of the need for change and reform in HE. This continued study aspires to provide a knowledge contribution regarding how, given the possibilities, which technology offers, the importance of connecting lifelong learning, change and reform in higher education.

\section{References}

Auger, J. F. (2008). Book Review: Mark Petticrew and Helen Roberts. Systematic reviews in the Social Sciences: A practical guide. Sociology, 42(5), 1032-1034.

Brady, S. R. (2015). Utilizing and Adapting the Delphi Method for Use in Qualitative Research. International Journal of Qualitative Methods, 2015, 1-6.

Broucker, B., de Wit, K., \& Leisyte, L. (2016). Higher education reform. A systematic comparison of ten countries from a new public management perspective. In. R.M.O. Pritchard, A. Pausits, \& J. Williams (Eds.), Positioning Higher Education Institutions: From Here to There (pp. 19-40). Rotterdam, SensePublsihers.

Bryce, R., Iglesias, R., Pullman, A., \& Rogova, A. (2016). Inequality Explained: The hidden gaps in Canada's education system. Open Canada, Jan, 19.

Cleveland-Innes, M. (2020). Student demographic change and pedagogical issues in higher education. In Inequality, Innovation and Reform in Higher Education (pp. 159173). Springer, Cham.

Delors, J. et al. (1996). Learning: The treasure within. Report to UNESCO of the International Commission on Education for the Twenty-first Century. UNESCO Digital Library. https://unesdoc.unesco.org/ark:/48223/pf0000109590

Duderstadt, J. J. (2009). A university for the $21^{\text {st }}$ century. University of Michigan Press.

Jaldemark, J. (2020). Formal and informal paths of lifelong learning: Hybrid distance educational settings for the digital era. In M. Cleveland-Innes \& R. Garrison (Eds.), An introduction to distance education: Understanding teaching and learning in a new era ( $2^{\text {nd }}$ ed., pp. 25-42). New York: Routledge. 
Jarvis, P. (2014). From adult education to lifelong learning and beyond. Comparative Education, 50(1), 45-57.

Jones, R. S. (2013). Education reform in Korea. http://www.brunner.cl/wpcontent/uploads/2013/07/5k43nxs1t9vh.pdf

Keeling, R., \& Hersh, R. (2011). We're losing our minds: Rethinking American higher education. Springer.

Petticrew, M., \& Roberts, H. (2008). Systematic reviews in the social sciences: A practical guide. New York, NY: John Wiley \& Sons.

Slowey, M., \& Schuteze, H. (2002). Participation and exclusion-a comparative analysis of non-traditional and lifelong learners in higher education. Higher Education: International Journal of Higher Education and Educational Planning, 44, 309-32.

Suri, H., \& Clarke, D. (2009). Advancements in research synthesis methods: From a methodologically inclusive perspective. Review of Educational Research, 79(1), 395430. 